\title{
An Examination of Prevalence of Earnings Management in Asia REITs
}

\author{
Siew Bee Thai ${ }^{1} \&$ Ming Ming Lai ${ }^{2}$ \\ ${ }^{1}$ Faculty of Management, Multimedia University, Persiaran Multmedia, Malaysia \\ Correspondence: Siew Bee Thai, Faculty of Management, Multimedia University, Persiaran Multmedia, 63100 \\ Cyberjaya, Selangor Darul Ehsan, Malaysia. E-mail: sbthai@mmu.edu.my \\ Received: February 12, 2019 \\ Accepted: March 15, 2019 \\ Online Published: April 18, 2019 \\ doi:10.5539/ijbm.v14n5p75 \\ URL: https://doi.org/10.5539/ijbm.v14n5p75
}

\begin{abstract}
This study examines the prevalence of earnings management in Real Estate Investment Trust (REIT) funds in Asia. Discretionary Accruals (DA) is used as the measurement of earnings management. A panel data covering all REIT firms in three countries: Malaysia, Singapore and Hong Kong, from year 2007 to 2015 is used for this purpose. The results show all firms having the absolute value of discretionary accruals indicating that earnings management exists in Asian REITs. Further, independent t-test shows that earnings management activities are significantly prevalent in all these three countries despite the regulatory structure of REITs.
\end{abstract}

Keyword: earnings management, REITs, discretionary accruals, Asia

\section{Introduction}

In corporate finance or accounting literature, earnings management is a common issue faced by the corporation. Attention has been directed to the study of earnings management activities from both the positive; such as efficient contracting, information perspectives; and the negative perspective; such as opportunistic behaviour (Holthausen, 1990).

Real Estate Investment Trust, also known as REITs, are no exception. They face the same problem (Anglin, Edelstein, Gao, \& Tsang, 2012; Deng \& Ong, 2014) and most previous studies have found that the occurrence of earnings management is driven by the agency problem discussed in the agency theory (Tang \& Chang, 2013; Teoh, Wong, \& Rao, 1998). Separation of the principal (shareholders) and agent (managers) leads to the agency conflict ultimately resulting in the agency cost to the company (Jensen, 1986) such as compensation plans such as bonuses, promotion and employee stock option plan that are used to align the interest of shareholders and manager (Murphy, 1985).

The manipulation of earnings using accounting treatment has led to the collapse of Enron (2001) and Lehman Brothers (2008) in U.S. The accrual method in accounting provides financial manager's the discretion in determining the use of accounting standards to report the transaction presented in the financial statement (Subramanyam, 2014). Under this condition, it provides the opportunity to manipulate earnings by managers to achieve their own interest at the shareholders' expenses (Holthausen, 1990). Previous study by Baik, Billings and Morton (2008) find that the motives of earnings management by managers is to meet the earnings benchmark while Alcock, Glascock \& Steiner (2013) find that fund managers tend to manipulate the earnings figure to enhance fund performance in order to be rewarded with managerial compensation. Besides, Ambrose \& Bian (2010) find that managers manipulate the share price through earnings management in order to attract investors to purchase the shares in U.S. REITs.

Studies on earnings management in Asian REITs are still lacking, with most carried out on U.S.REITs (Alcock et al., 2013; Ambrose \& Bian, 2009; Deng \& Ong, 2018; Edelstein, Liu, \& Tsang, 2008; Zhu, Ong, \& Yeo, 2010a). Edelstein et al. (2008) find evidence of REITs with cash constraint in U.S. mitigate the effects of dividend pay-out regulations by engaging in real earnings management (REM) activities either by reducing revenue or increasing expenses which would reduce the taxable income. Besides, Ambrose et al. (2010) find that information contained in stock price volatility motivates REIT managers to engage in negative real earnings management to avoid more actively the regulatory costs by avoiding the mandatory dividend pay-out requirement. On the other hand, Zhu et al. (2010a) find that REITs which more frequently issue seasoned equity 
offerings (SEOs) are more aggressive in manipulating funds from operations (FFO) compared to earnings. In addition, Deng \& Ong (2018) show that REITs managers engage in real earnings management instead of accrual earnings management during seasoned equity offerings to attract more uninformed trading with the purpose to provide the liquidity service at a lower cost.

The above studies are mainly conducted in U.S. REITs and most of them use real earnings management (REM) and manipulation of fund from operation (FFO) as the measurement of earnings management. In view of REITs increasing popularity in Asia and its status as an exotic investment alternative for investors in Asia with market capitalization expected to reach around US\$200 billion by 2020 (Ooi, Newell, \& Sing, 2006), this study is conducted to examine the prevalence of earnings management activities in Asian REITs particularly in Malaysia, Singapore and Hong Kong using the discretionary accruals method. The use of discretionary accruals in this study compared to real earnings management to detect the earnings management activities in REITs is due to most of the previous studies are focus on real activities of earnings management (Deng \& Ong, 2018; Edelstein et al., 2008). The use of discretionary accruals to detect the earnings management especially in Asia REITs is still lacking. In discretionary accruals method, managers have the discretion to manipulate earnings figures using the accounting treatment without getting involved in real manipulation of operation activities such as reduction in R\&D expenditure or reduction in the cost of goods sold (COGS) in order to increase the net income figure. On the other hand, the fund from operation is an industry -specific measure which provides another option to measure the REITs performance and is recommended by the National Association of Real Estate Investment Trust (NAREIT) (Anglin et al., 2012). However, the data of funds from operation in Asia REITs is limited and not common compared to U.S. REITs. In addition, to measure earnings management using manipulation of fund from operations (FFO) is not as accurate as using discretionary accruals and real activities management because the fund from operation figure is not audited by the auditor.

This paper provides significant contribution to the current literature in REITs as most previous studies in earnings management are focusing on U.S. REITs. The study of earnings management in REITs is important mainly due to the regulatory requirement of $90 \%$ dividend payout which is believed to be able to reduce the agency problem that causes earnings management activities in REITs. However, the evidence of prevalence of earnings management in Asia REITs is still inconclusive. Panel data from all REITs in Malaysia, Singapore and Hong Kong from year 2007 to 2015 are used to investigate the prevalence of earnings management activities in Asian REITS and the measurement of earnings management is done using Modified Jones Model as described in the study of Dechow, Sloan \& Sweeney (1995).

The remainder of this paper is structured as follows. Section 2 presents the literature review. Section 3 explains the data and research methodology. Section 4 discusses the empirical results and Section 5 concludes the findings.

\section{Literature Review}

REITs in Asia especially in Malaysia, Singapore and Hong Kong are still externally managed with the separation of principal (shareholder) and agent (manager). Under this condition, the agency theory developed by Jensen \& Meckling (1976) posits that agency conflict which arises as a result of the agency problem could cause the managers to not act in the best interest of the shareholders. In order to solve this problem, compensation plans are used by top management to align the interest of both the managers and shareholders and this brings agency costs to the firm. REITs, which are similar to conventional corporations listed on the stock exchange, face the agency problem as well. Evidence from previous studies on REITs show that earnings management in REITs is mainly driven by the agency problem. Earnings management activities in REITs could be due to the managers pursuing their own interest through earning-reducing manipulations in order to reduce the regulatory dividend pay-out of $90 \%$ in REITs. The reduction in dividends creates free cash flow where the manager may consume it in his or her own interest instead of in the shareholders' best interest (Bauer, Eichholtz, \& Kok, 2006). Jensen (1986) argues that the conflict of interest between managers and shareholders become severe when more free cash flows are involved. As a result, it exacerbates the agency problem such as empire building and perquisite consumptions at the expense of shareholders (Ambrose \& Bian, 2009; Edelstein et al., 2008; Ghosh \& Sun, 2013). Furthermore, the manipulation of fund performance figure to enhance evaluation outcomes in order to get their managerial compensation and reputation would be another agency problem that can encourage earnings management activities in REITs (Alcock et al., 2013; Ghosh \& Sirmans, 2006). In addition, the manipulation of earnings figure during seasoned equity offerings (SEO) or initial public offerings (IPO) to increase the share price in order to attract investors to buy their new shares exhibits another agency problem in REITs. The consequence is that the performance of REITS would deteriorate during the post SEO or IPO period due to the reversal of accruals manipulation (Deng \& Ong, 2014, 2018; Huaisheng, 2008; Sah \& Seagraves, 2010; Zhu, 
Ong, \& Yeo, 2010b).

According to the accruals method in accounting, financial manager has the discretion in determining the use of accounting standards to report transactions presented in the financial statement (Subramanyam, 2014). Besides, financial manager also has discretion in making estimations of uncertain future outcomes. The most common meaning of accruals is the adjustment in accounting that converts the operating cash flow to net income by adding the accruals to the operating cash flow. Schipper (1989) defines earnings management as intentional intervention by management in the earnings determination process in order to satisfy the self- interested objectives. The motivations for earnings management includes contracting incentives such as managerial compensation contracts which often reward the manager with bonuses based on earnings (Subramanyam 2014). Thus, this has caused the manager to manage earnings within a certain range in order to be rewarded with the bonuses.

Edelstein et al. (2009) investigate how cash constrained U.S. Real Estate Investment Trusts (REITs) mitigate the effects of dividend pay-out regulations by engaging in real earnings management (REM). The sample consist of all U.S. REITs for the period from 2000 to 2005 with a final sample contains of 330 firm-year observations. This study uses dividend pay-out ratio based on FFO as a substitute for the unobserved dividend-to-taxable income ratio to identify REITs that may face difficulties in paying required dividends. The results show that firms are more likely to engage in real earnings management (REM) activities either by reducing revenue or increasing expenses which would reduce taxable income. In addition, the findings show REITs are more likely to engage in REM by selling fixed assets (even at a loss) to generate the necessary cash, at the same time to alter the dividend payment requirements under the condition of facing constraint to obtain funding from the capital market or having less cash flow from operations.

Ambrose and Bian (2010) examine the relationship between stock price movement and earnings management in REIT. Besides, the study also investigates whether information produced from stock price volatility impacts managers' motivations to involve in earnings management. The sample comprises of 104 unique REITs with 655 firm-year observations from year 1999 to 2006 . The result show suspected earnings-management firms do not appear to be more mispriced than others which consistent with the efficient markets hypothesis. Besides, the results also indicate that negative real earnings management, which allows REITs to avoid the mandatory dividend pay-out requirement, is associated with greater information which embedded in REIT stock prices. The result indicates that information contained in stock price volatility motivates REIT managers to avoid more actively the regulatory costs.

Zhu, Ong and Yeo (2010a) examined the existence of earnings management around seasoned equity offerings (SEO). The sample contains 251 SEOs from 90 REITs with sample period from 2001Q1 through 2006Q4 with a total of 24 consecutive quarters using discretionary accruals methods as measurement of earnings management. Besides, the difference between actual and calculated FFO is used to capture the potential FFO manipulation. The study examined how these manipulation measures changed in the five quarters around SEOs. In addition, they investigate how financial structure, operating style, external auditor and corporate governance affect a REIT's earnings management decision. The results show clear evidence of FFO manipulation around SEOs, but the degree of earnings management is relatively weaker. They find that REITs issuing SEOs more frequent are more aggressive in manipulating FFO than earnings. Moreover, there is a prominent difference between these two types of financial results manipulation. A mean-reversion trend is found in discretionary accruals, but not for FFO manipulation. Manipulation in financial results are influenced by various factors. A reduced capability to generate cash flow, high leverage, volatile cash flow, frequent SEOs and lack of corporate governance are all the features of REITs more likely to manipulate financial results.

Alcock, Glascock, and Steiner (2013) examine whether managers perform manipulation of fund performance of REITs actively in U.S. despite the strict regulatory of structure REITs. The sample data comprises of 147 REITs from 1991 to 2009 covering seven property sectors. The results show that opportunistic manipulation of fund performance using leverage become a norm as the competition in the property sector become severe. The findings further indicate that REITs fail to constraint the agency problem despite the regulatory structure.

Deng and Ong (2018) examine how REITs managers apply real earnings management to address the problem of liquidity risk and increased cost of capital they face during seasoned equity offerings. The sample data comprises of 508 seasonal equity offerings from 119 equity REITs in the period from January 1, 2000 to December 31, 2011. The results indicate that REITs managers engage in real earnings management instead of accrual earnings management during seasoned equity offerings to attract more uninformed trading with the purpose to provide the liquidity service at a lower cost. Besides, the findings show REITs with higher liquidity risk are more prone to 
manipulate earnings before the equity offerings and uninformed trading is higher following real earnings management. Furthermore, firms set the offer price at a smaller discount after engaging in real earnings management and stock returns decrease in the long run. The findings are consistent with real option and liquidity risk explanations for equity offerings.

In a nutshell, there is limited research examining earnings management activities in Asian REITs compared to REITs in U.S. This could be due to the development of REITs in Asia being at the embryonic stage as compared to a more mature U.S. REITs market. It is important to study the agency issue pertaining to the occurrence of earning management in Asia REITS. This empirical study is carried out to provide a considerable insight into the occurrence of earnings management which caused by the agency problem.

\section{Data and Research Methodology}

\subsection{Data Collection}

The sample of this study comprises of all REITs companies listed in Malaysia, Singapore and Hong Kong from the period of 2007 to 2015. All the variables are collected from the Bloomberg database and annual report. This includes the variables that need to be used to derive the Discretionary Accruals (DA). There are 41 REITs firms with 13 REITs from Malaysia, 21 REITs from Singapore and 7 REITs from Hong Kong. This yields a total of 264 of firm -year observations. The unequal number of observations of REITs in these three countries are due to the different time line in introducing the REITs in each country respectively and also due to the missing data. The sample includes only these three countries as they are similar in terms of structure, i.e. the REITs are externally managed and they are considered as the leaders in the REITs market in Asia. Besides, these three countries having the same of corporate governance code.

Asia's REIT markets have performed well over the past five years. A recent study by the Asia Pacific Real Estate Association found that REITs in Japan, Hong Kong and Singapore have outperformed stocks in these markets since their inception and since the start of the global financial crisis. Besides, Asia's REITs have also outperformed their peers in other regions. A five-year investment into Asia's REITs in January 2008 would have achieved a cumulative return of about $42 \%$ as measured by the Bloomberg Asia REIT Index. This exceeds the cumulative return for U.S. REITs of about $31 \%$ as measured by the FTSE NAREIT All REITs Total Return Index and nearly a $14 \%$ total return of global REITs as measured by the FTSE EPRA/NAREIT Developed Total Return Index in the same period. Asian REITs also delivered lower volatility of approximately $20 \%$ compared to both U.S. REITs at about $31 \%$ and global REITs at approximately $28 \%$, over the same period (Adopted from Asia Asset Management, 2018).

Unfortunately, to the authors' best knowledge, there is little to no research so far on the examination of earnings management in Asia REITs especially in Malaysia, Singapore and Hong Kong. Most of the studies are done in U.S. REITs (Alcock et al., 2013; Ambrose et al., 2010; Anglin, Edelstein, Gao, \& Tsang, 2013; Deng \& Ong, 2018; Edelstein et al., 2008; Huaisheng, 2008; Zhu et al., 2010b). The motives of earnings management in Asia may be different compared to the other countries given the different institutional environment with the existing corporate governance standard that the firms are operating. A different institutional and regulatory context may provide richer insights into the outcomes of the study that works only in this perspective. Finally, the REITs structure in Malaysia, Singapore and Hong Kong are the same; i.e. they are externally managed.

\subsection{Research Method}

To measure earnings management in REITs, discretionary accruals (DA) method is used based on the modified Jones model as describe in the study of Dechow, Sloan, \& Sweeney (1995). DA represents the portion of accruals that does not arise from regular business operations and is expected to be the outcome of managers exercising their discretion to influence the financial results. Since accruals reverse over time and manager may have motivations to manage reported earnings in either direction (to overstate or understate earnings), the absolute value of discretionary accruals $\left(A B S_{-} D A\right)$ is calculated and this serves as the basis of the measurement of accrual earning management (Anglin et al. 2012).

The mathematical form of discretionary accruals (DA) is as follows:

$$
\operatorname{TACC}_{j, t}=\alpha_{1, t}+\beta_{1, t} \Delta R E V_{i, t}+\beta_{2, t} P P E_{i, t}+\varepsilon_{i, t}
$$

Where:

$T A C C_{i, t}$ is total net income accrual of the firm $\mathrm{i}$ at time $\mathrm{t}$

$\triangle R E V_{i, t}$ is change in revenue from the preceding year of the firm $\mathrm{i}$ at time $\mathrm{t}$

$P P E_{i, t}$ is total value of real estate property of the firm $\mathrm{i}$ at time $\mathrm{t}$ 
All variable in the above equation are scaled by the previous years' total assets to control for the effect of heteroskedasticity (Anglin et al., 2012).

Total net income accruals is defined as the difference between income before extraordinary items (IB) and cash flows from operating activities (CFO):

$$
T A C C_{i, t}=I B_{i, t}-C F O i, t
$$

where:

$I B i_{, t}$ is income before extraordinary items of firm $\mathrm{i}$ at time $\mathrm{t}$

$C F O i, t$ is cash flow from operating activities

The estimation from the regression equation in Eq. (1) above are used to approximate the firm specific expected, non- discretionary level of accruals (NDA) for the sample REITs:

$$
N D A_{j, t}=\hat{\alpha}_{1, t}+\hat{\beta}_{1, t}(\Delta R E V j, t-\Delta A R j, t)+\widehat{\beta}_{2, t} P P E_{j, t}
$$

Where:

$N D A_{i, t}$ is non-discretionary level of accruals of firm $\mathrm{i}$ at time $\mathrm{t}$

$\Delta A R i,{ }_{t}$ is the change in accounts receivable from preceding year of firm i at time $\mathrm{t}$ (scaled by previous year's total assets).

Finally, the DA is derived by subtracting NDA from TACC as shown in the following Equation (4).

$$
D A_{i, t}(\text { Discretionary accruals })=T A C C_{i j, t}-N D A_{i, t}
$$

Where:

$D A_{i, t}$ is discretionary accruals of the firm $\mathrm{i}$ at time $\mathrm{t}$

\section{Result and Discussion}

\subsection{Descriptive Statistics}

Table 1 summarises the descriptive statistics for Discretionary Accruals. The mean of Discretionary Accruals (DA) for all firms is 0.086959 in dollar amount of absolute value. According to the Jones model, as long as the value of DA is larger than 0 in absolute value, it shows the existences of earnings management as measured by DA. The highest discretionary accruals for all firms are 1.65 dollars while the lowest is 0.00019 dollar. Among the three countries, Malaysia scores the highest mean of DA with 0.100667 while Singapore with the lowest mean of 0.075415. However, Singapore has the highest value of maximum DA with 1.65 and also lowest value of minimum DA with 0.00019 . The standard deviation of DA for all firms is 0.195496 and Singapore having the nearest of standard deviation of 0.1847 . Skewness of discretionary accruals for all firms exhibits a positive value

\begin{tabular}{|c|c|c|c|c|c|c|c|c|}
\hline Country & Obs & Median & Mean & Std. Dev. & Min & Max & Skewness & Kurtosis \\
\hline All Three Countries (Malaysia, & & & & & & & & \\
\hline Singapore and Hong Kong) & 264 & 0.0286397 & 0.0869591 & 0.1954964 & 0.0001896 & 1.650131 & 5.0021 & 31.73758 \\
\hline Malaysia & 90 & 0.0209146 & 0.1006665 & 0.2388377 & 0.0014305 & 1.312136 & 3.843241 & 17.74357 \\
\hline Singapore & 129 & 0.0293645 & 0.0754152 & 0.1846998 & 0.0001896 & 1.650131 & 6.10851 & 46.75314 \\
\hline Hong Kong & 45 & 0.0602974 & 0.0926371 & 0.1140718 & 0.0059555 & 0.6671402 & 3.124454 & 15.47941 \\
\hline
\end{tabular}
indicating that most of the REITs firms have below average discretionary accruals.

\begin{tabular}{|c|c|c|c|c|c|c|c|c|}
\hline \multicolumn{9}{|c|}{ Descriptive Statistics For Discretionary Accruals } \\
\hline Country & Obs & Median & Mean & Std. Dev. & Min & Max & Skewness & Kurtosis \\
\hline All Three Countries (Malaysia, & & & & & & & & \\
\hline Singapore and Hong Kong) & 264 & 0.0286397 & 0.0869591 & 0.1954964 & 0.0001896 & 1.650131 & 5.0021 & 31.73758 \\
\hline Malaysia & 90 & 0.0209146 & 0.1006665 & 0.2388377 & 0.0014305 & 1.312136 & 3.843241 & 17.74357 \\
\hline Singapore & 129 & 0.0293645 & 0.0754152 & 0.1846998 & 0.0001896 & 1.650131 & 6.10851 & 46.75314 \\
\hline Hong Kong & 45 & 0.0602974 & 0.0926371 & 0.1140718 & 0.0059555 & 0.6671402 & 3.124454 & 15.47941 \\
\hline
\end{tabular}

Table 1. Descriptive statistics for discretionary accruals 


\subsection{Estimation and Diagnostics}

Empirical analysis to examine significant differences in earnings management activities, as measured by discretionary accruals, across the three countries is carried out using Kruskal-Wallis Equality of Population Rank Test. The results of the analysis is provided in Table 2 .

Table 2. Kruskal-Wallis equality of populations Rank Test for DA (by Country)

\begin{tabular}{llll}
\hline Country & Obs & Rank Sum & Kruskal-Wallis test \\
\hline Malaysia & 90 & 11084 & chi-squared $=10.788$ with 2 d.f. \\
Singapore & 129 & 16412 & probability $=0.0045$ \\
Hong Kong & 45 & 7484 & chi-squared with ties $=10.788$ with 2 d.f. \\
Total & 264 & & probability $=0.0045$ \\
\hline
\end{tabular}

Referring to Table 2, it is found that there is a significant difference in the discretionary accruals among the countries with the p-value being smaller than 0.01 ( $1 \%$ significant level). Malaysian REITS having the highest mean DA while Singapore has the lowest mean DA. Discretionary accruals measure earning management activities in the firms. Earning management however can be good or bad. According to previous studies, earnings management can be constrained by strong corporate governance mechanisms (Chtourou \& Bedard, 2001; Peasnell, Pope, \& Young, 2005; Xie, Davidson, \& Dadalt, 2003). The lower of DA in Singapore REITs could be due to REITs in Singapore having stronger corporate governance mechanism with the R- Index introduced by Lecomte and Ooi (2010). Meanwhile, the lack of such corporate governance index specifically for REITS results in weaker corporate governance in Malaysian REITs and this could be explained by the higher DA in Malaysian REITs. Therefore, the differences in the DA in each country may be due to the lack of implementation of corporate governance rules in the respective countries.

\subsection{Discussion of Results}

From the one sample t- test results, earnings management was found to be significantly prevalent in REITs firms in all the countries. This favourable result is consistent with prior studied by Ambrose and Bian (2009), Ambrose et al. (2010), Zhu, Ong, and Yeo (Zhu et al., 2010a) and Anglin et al. (2012).

The prevalence of earnings management in REITs is in line with the agency theory. The implication of the agency theory is that conflict of interest arises between managers and shareholders due to the managers pursue their own interest instead of shareholders when making decision in the company. Based on previous literature, the motive of earnings management in REITs can be caused by a few factors. First, earnings management in REITs could be caused by managers pursuing their own interests by employing earnings-reducing manipulations to reduce the regulatory dividend pay-out of $90 \%$ in REITs. The reduction in dividend pay-out would reduce the wealth of the shareholders. As a result, it exacerbates agency problems such as empire building and perquisite consumptions at the expense of the shareholders (Ambrose \& Bian, 2009; Edelstein et al., 2008; Ghosh \& Sun, 2013). Furthermore, under the asymmetry information condition, the incentive for managers to deceive investors through overstated earnings might increase and thus give a "false' positive impact on firm performance.

Second, REITs managers manipulate risk-adjusted performance measures to enhance evaluation outcomes in order to get their managerial compensation and reputation which often depend on performance evaluation outcomes using measures such as Jensen's alpha (Jensen, 1968), the Sharpe ratio (Sharpe, 1966) and information ratios or the Stutzer index (Stutzer, 2000). A priori, REIT managers have the same motivation to manipulate performance measures similar to fund managers from other asset classes despite strict regulation under the REITs regime. The regulatory setting and tax-exempt status of REITs provides appropriate flexibility in the capital structure to exploit the benefits of more aggressive capital structure strategies. The outcome from this manipulation would lead to an increase of firm performance which misleads the investors about the performance of the REITs firms. (Alcock et al., 2013).

Third, previous studies show the manipulation of earnings figure especially during seasoned equity offerings (SEO) or initial public offerings (IPO) is due to managers using discretionary accruals to increase the share price in order to attract investors to purchase their stock during the SEO or IPO. As a result, it gives a positive impact towards the firm performance. However, the positive impact on firm performance only exists during the year and the following year when the earnings management is conducted, after which it diminishes. This is because the use of accruals-based manipulation of earnings figure to increase the operating performance would attract the investors to purchase the new offerings during SEO or IPO. Subsequently, after the period of SEO, the 
performance of firm would deteriorate primarily due to the accrual reversals. The manipulation in financial results is influenced by various factors. A diminished capability to generate cash flow, high leverage, volatile cash flow, frequent SEOs and slack corporate governance are all the features of REITs that make it more likely to manipulate financial results (Ambrose et al., 2010; Deng \& Ong, 2014, 2018; Huaisheng, 2008; Sah \& Seagraves, 2010; Shu \& Chiang, 2014; Zhu et al., 2010a).

\section{Conclusion}

The findings from this study show that earnings management, measured via discretionary accruals, is prevalent in Asian REITs especially in Malaysia, Singapore and Hong Kong. The findings from this study can be used as useful information for regulators of REITs in their effort to mitigate the negative impact of earnings management. Besides, it also provides useful insight to the investors in REITs in monitoring the activities of the managers that engage in earnings management with the purpose of fulfilling their self -interest such as empire building or entrenchment power.

This study contributes to the limited literature on earnings management activities in Asian REITs. This study uses discretionary accruals as the measurement of earnings management activities in Asian REITs. The panel data for the country of Malaysia, Singapore and Hong Kong are used to derive the value of discretionary accruals. The results show the absolute value of DA is larger than zero for all the firms under this study, indicating that earnings management exists in Asian REITs. Further, one sample t- test results show earnings management to be significantly different in REITs firms in all the countries. This is consistent with prior studies by Ambrose \& Bian (2009), Ambrose et al. (2010), Zhu, Ong, \& Yeo (Zhu et al., 2010a) and Anglin et al. (2012).

As a conclusion, despite the unique structure of REITs where a mandatory dividend pay-out $90 \%$ of total taxable income is imposed and it is believed to be able to mitigate the agency problem in REITs, this study show the earnings management problem still exists in REITs, indicating that there is a need for specific governance mechanisms that can mitigate this problem in Asian REITs. (Ben-Shahar, Sulganik, \& Tsang, 2010; Edelstein et al., 2009; Ghosh \& Sirmans, 2006; Ghosh \& Sun, 2013; Hayunga \& Stephens, 2009; Lee, Chiu, Lee, Chiang, \& Jr, 2010; Mooradian \& Yang, 2001).

The limitation of this study is this study using the discretionary accruals in measuring the earnings management figure in REITs. Due to the lack information of funds from operations in each country's REITs firms, the use of FFO is not considered in this study. Future studies may use manipulation of funds from operation (FFO) and real activities of earnings management (REM) as the measurement of earnings management. Besides, the future studies can include more countries in Asia such as Japan, Thailand and Philippine. A longer time period of study is also recommended upon the availability of data.

\section{References}

Alcock, J., Glascock, J., \& Steiner, E. (2013). Manipulation in U . S . REIT Investment Performance Evaluation : Empirical Evidence. Journal Real Estate Finance Economy, 47, 434-465. https://doi.org/10.1007/s11146-012-9378-8

Ambrose, B. W., \& Bian, X. (2009). Stock Market Information and REIT Earnings Management. Retrieved from $\mathrm{http}$ //apps.isiknowledge.com/full_record.do?product=WOS\&search_mode=GeneralSearch\&qid=1\&SID=3 DSLdJJRjAsSGQvBCV8\&page $=6 \&$ doc $=263$

Ambrose, B. W., \& Bian, X. (2010). Stock Market Information and REIT Earnings Management. JRER, 32(1), 101-137. Retrieved

from http://apps.isiknowledge.com/full_record.do?product=WOS\&search_mode=GeneralSearch\&qid=1\&SID=3 DSLdJJRjAsSGQvBCV8\&page $=6 \& d o c=263$

Anglin, P., Edelstein, R., Gao, Y., \& Tsang, D. (2012). What is the Relationship Between REIT Governance and Earnings Management? The Journal of Real Estate Finance and Economics, 47(3), 538-563.

Anglin, P., Edelstein, R., Gao, Y., \& Tsang, D. (2013). What is the Relationship Between REIT Governance and Earnings Management? The Journal of Real Estate Finance and Economics, 47(3), 538-563. https://doi.org/10.1007/s11146-012-9367-y

Asia Asset Management. (2018). The rise of Asia's REITs - Asia Asset Management. The Journal of Investments \& Pension. Retrieved from file://G:/New Articles 021018/The rise of Asia's REITs - Asia Asset Management - The Journal of Investments \& Pensions.html

Baik, B., Billings, B. K., \& Morton, R. M. (2008). The Effect of Increased Transparency on Manipulation and Value Relevance of Non- GAAP Disclosure by Real Estate Investment Trust (REITs). The Accounting 
Review, 83(2), 271-301. Retrieved from https://dx.doi.org/10.2139/ssrn.900849

Bauer, R., Eichholtz, P. M. A., \& Kok, N. (2006). Corporate Governance and Firm Valuation: The REIT-Effect (Vol. 31).

Ben-Shahar, D., Sulganik, E., \& Tsang, D. (2010). Funds From Operations Versus Net Income: Examining The Dividend- Relevance of REIT Performance Measures, 1-32.

Chtourou, S. M., \& Bedard, J. (2001). Corporate Governance and Earnings Management. Social Science Research Network (SSRN), 4(418), 1-39. https://doi.org/10.2139/ssrn.275053

Dechow, P. M., Sloan, R. G., \& Sweeney, A. P. (1995). Detecting Earnings Management. The Accounting Review, 70(2), 193-225. https://doi.org/10.2307/248303

Deng, X., \& Ong, S. E. (2014). Real Earnings Management, Liquidity and REITs SEO dynamics. In AREUEA-ASSA Annual Meeting, Philadelphia, PA, 3-5 January 2014 (pp. 1-39). Retrieved from https://link.springer.com/article/10.1007/s11146-017-9649-5

Deng, X., \& Ong, S. E. (2018). Real Earnings Management, Liquidity Risk and REITs SEO Dynamics. Journal of Real Estate Finance and Economics. https://doi.org/10.1007/s11146-017-9649-5

Edelstein, R., Liu, P., \& Tsang, D. (2008). Real Earnings Management and Dividend Payout Signals: A Study for U.S. Real Estate Investment Trusts. SSRN. https://doi.org/10.2139/ssrn.1079984

Edelstein, R., Tsang, D., \& Liu, P. (2009). Real Earnings Management and Dividend Payout Signals : A Study for U . S . Real Estate Investment Trusts, 1-34. https://doi.org/https://dx.doi.org/10.2139/ssrn.1079984

Ghosh, C., \& Sirmans, C. F. (2006). Do managerial motives impact dividend decisions in REITs? J Real Estate Financial Economics, 32, 327-355. https://doi.org/10.1007/s11146-006-6805-8

Ghosh, C., \& Sun, L. (2013). Agency Cost, Dividend Policy and Growth: The Special Case of REITs. Journal of Real Estate Finance and Economics, 1-49. https://doi.org/10.1007/s11146-013-9414-3

Hayunga, D. K., \& Stephens, C. P. (2009). Dividend behaviour of US equity REITs. Journal of Property Research, 26(2), 105-123. https://doi.org/10.1080/09599910903441549

Holthausen, R. W. (1990). Accounting Method Choice: Opportunistic Behavior, Efficient Contracting, and Information Perspectives. Journal of Accounting and Economics, 12, 207-218. https://doi.org/https://doi.org/10.1016/0165-4101(90)90047-8

Jensen, M. C. (1968). The Performance of Mutual Funds in the Period 1945-1964. The Journal of Finance, 23(2), 389. https://doi.org/10.2307/2325404

Jensen, M. C., \& Meckling, W. H. (1976). Theory of the Firm: Managerial Behaviour, Agency Costs y Ownership Structure. Journal of Financial Economics, 3(4), 305-360. https://doi.org/Doi: $10.1016 / 0304-405 x(76) 90026-x$

Jensen. (1986). Agency Costs of Free Cash Flow, Corporate Finance, and Takeovers. American Economic Review, 76(2), 323-329. https://doi.org/10.2139/ssrn.99580

Lecomte, P., \& Ooi, J. T. L. (2010). Corporate Governance Of Asian REITs : Introducing A New Framework Of Analysis. In The European Real Estate Society 17th Annual Conference (Milano, Italy) (pp. 1-47). https://doi.org/https://eres.architexturez.net/doc/oai-eres-id-eres2010-248

Lee, M. T., Chiu, B.-H., Lee, M. L., Chiang, K. C. H., \& Jr, V. C. S. (2010). REIT excess dividend and information asymmetry: evidence with taxable income. Journal of Property Investment \& Finance, 28(3), 221-236. https://doi.org/10.1108/14635781011048867

Mooradian, R. M., \& Yang, S. X. (2001). Dividend Policy and Firm Performance: Hotel REITs vs non-REIT Hotel Companines. Journal of Real Estate Portfolio Management, 7(1), 79-87. Retrieved from k:\%5CData Disk\%5CReadings\%5CDownloads (Catalogued)\%5C000000069804112-1-6.pdf

Murphy, K. J. (1985). Corporate Performance and Managerial Remuneration: An Empirical Analysis. Journal of Accounting and Economics, 7, 11-42. https://doi.org/https://doi.org/10.1016/0165-4101(85)90026-6

Ooi, J. T. L., Newell, G., \& Sing, T. (2006). The Growth of REIT Markets in Asia. Journal of Real Estate Literature, 14(2), 203-222. Retrieved from http://scholarbank.nus.edu.sg/handle/10635/46314

Peasnell, K. V., Pope, P. F., \& Young, S. (2005). Board monitoring and earnings management: Do outside directors influence abnormal accruals? Journal of Business Finance and Accounting, 32(7-8), 1311-1346. 
https://doi.org/10.1111/j.0306-686X.2005.00630.x

Sah, V., \& Seagraves, P. (2010). IPO Market Timing: Evidence from the Operating Perfromance of REITs, 1-24.

Schipper, K. (1989). Commentary: Earnings management. Accounting Horizons, 3(4), 91-102.

Sharpe, W. F. (1966). Mutual Fund Performance. The Journal of Business, 39(1119-138). Retrieved from https://www.jstor.org/stable/2351741

Shu, P., \& Chiang, S. (2014). Firm size, timing, and earnings management of seasoned equity offerings. International Review of Economics and Finance, 29, 177-194. https://doi.org/10.1016/j.iref.2013.05.011

Stutzer, M. J. (2000). A Portfolio Performance Index. Financial Analyst s Journal, 54. Retrieved from https://www.jstor.org/stable/4480247

Subramanyam, K. R. (2014). Financial Statement Analysis (pp. 108-115). Retrieved from https://hort.iastate.edu/financial_statement_analysis_subramanyam_11th_edition.pdf

Tang, H. W., \& Chang, C. C. (2013). Does corporate governance affect the relationship between earnings management and firm performance ? An endogenous switching regression model. Rev Quant Finan Acc, 126. https://doi.org/10.1007/s11156-013-0427-z

Teoh, S. H., Wong, T. J., \& Rao, G. R. (1998). Are Accruals during Initial Public Offerings Opportunistic? Review of Accounting Studies, 3(1/2), 175-208. https://doi.org/10.1023/a:1009688619882

Xie, B., Davidson, W. N., \& Dadalt, P. J. (2003). Earnings management and corporate governance: The role of the board and the audit committee. Journal of Corporate Finance, 9(3), 295-316. https://doi.org/10.1016/S0929-1199(02)00006-8

Zhu, Y. W., Ong, S. E., \& Yeo, W. Y. (2010a). Do REITs manipulate their financial results around seasoned equity offerings? evidence from US equity REITs. Journal of Real Estate Finance and Economics, 40(4), 412-445. https://doi.org/10.1007/s11146-009-9227-6

Zhu, Y. W., Ong, S. E., \& Yeo, W. Y. (2010b). Do REITs manipulate their financial results around seasoned equity offerings? evidence from US equity REITs. Journal of Real Estate Finance and Economics, 40(4), 412-445. https://doi.org/10.1007/s11146-009-9227-6

\section{Copyrights}

Copyright for this article is retained by the author(s), with first publication rights granted to the journal.

This is an open-access article distributed under the terms and conditions of the Creative Commons Attribution license (http://creativecommons.org/licenses/by/4.0/). 